\title{
INTERPLANTING COWPEA, SQUASH AND JEW'S MALLOW WITH TARO
}

\author{
El-Miniawy, S.M.*; Zahra A. El-Sharkawy ${ }^{\star \star}$; M.M.F. Abdallah and \\ Amira M.M. Abuzeed**
}

* Horticulture Depart. Fac. of Agric. Ain Shams Univ. Shoubra ElKheima, Cairo, Egypt.

** Potato and Vegetatively Propagated Vegetable Depart. Horticultural Res. Inst. Agric. Res. Center, Giza, Egypt

\begin{abstract}
This work was carried out during two summer seasons, i.e., 2003 and 2004, to investigate the effect of interplanting cowpea, squash or Jew's mallow with taro on vegetative growth, chemical composition of taro corms, yield and its components, associated weeds, and land equivalent ratio. Significant decrease was observed in taro vegetative growth when interplanting with cowpea, squash and Jew's mallow. The vegetative growth of the companion crops were decreased by interplanting compared to sole crops. The highest values of chemical composition of taro corms $(\mathrm{N}, \mathrm{P}, \mathrm{K}$, protein and starch) were obtained by solid taro. Interplanting cowpea with taro increased taro yield as compared to sole crop or with either squash or Jew's mallow. In addition, yield of cowpea, squash and Jew's mallow was higher when they were grown alone than when they were interplanted with taro. The results indicated that interplanting cowpea or squash with taro reduced significantly number of weeds, fresh and dry weight of weeds $/ \mathrm{m}^{2}$ after 90 days from taro planting. However, interplanting Jew's mallow with taro had no effect on weed control. The highest yield was produced and land usage was increased due to interplanting cowpea with taro. The land usage was increased by $74 \%, 59 \%$ or $42 \%$ when interplanting cowpea, squash or Jew's mallow with taro, respectively, than that obtained if the unit area was planted with sole crops.

Generally, it may be concluded that interplanting cowpea with taro being the most effective and favorable treatments in most cases.

Keywords: Taro, Interplanting, Squash, Cowpea, Jew's mallow, Vegetative growth, Nitrogen, Phosphorus, Potassium, Protein, Starch, Yield, Weed control, Land equivalent ratio.
\end{abstract}

\section{INTRODUCTION}

Taro (Colocasia esculanta) is a monocotyledonous plant belonging to the family Araceae. It is considered one of the most important vegetables grown in Egypt due to its high nutritional and economical values. There are some factors that limit the increment of taro cultivation area such as its high need for fertilization, high amounts for irrigation water and its long duration in land (7-9 months). In addition, in the early period of plant growth, i.e., up to 90 days from sowing, the growth rate is low which causes an increasing in growing weeds. Also, interplanting is a factor that limits the spread of the associated weeds, i.e., interplanting helps in controlling weed population compared to sole cropping. Therefore, the potential application of intercropping may be a way to increase the productivity of land and increase the yield of unit area. The intercrop components may differ in their use of environmental sources in a way they can complement each other in time and space and they may use environmental sources more efficiently than when 
grown in monocrops, and perhaps produce a higher yield than monocropping (Willy, 1979). Legumes and non - legumes can complement each other in the use of nitrogen sources and legume $\mathrm{N}$ was transferred to non - legumes as reported by Jensen (1996), and this in turn decreases the pollution from $\mathrm{N}$ fertilizers. Concerning the effect of interplanting on vegetative growth of taro and other vegetable crops, Behairy (1969) reported that growing either bean or cucumber plants on the ridges of dasheen depressed the growth of dasheen (plant height, number of leaves per plant, length and width of blades).In addition, dasheen plants caused depressions in the growth of bean and cucumber plants expressed as plant height and number of leaves per plant. Rich and Hansen (1982) studied the growth of maize, beans and squash when grown in pure stands and mixtures. They found that vegetative biomass/ plant in squash were significantly smaller in mixture with maize than in pure stands. Ojeifo and Lucas (1987) in a study on intercropping Jew's mallow with tomato, they found that leaf area, plant height and dry weight were not significantly different from values obtained when Jew's mallow was grown alone. Abd El-Baky (1994) reported that interplanting squash on the ridges of okra reduced the dry matter content of squash plants and its different parts, i.e.,leaves,branches and roots, as compared to solid planting. Interplanting cowpea on the ridges of okra reduced the dry matter content of cowpea plants and its different parts, i.e., leaves, branches and roots, compared to plants grown alone. Fatthallah and Gawish (1997) found a significant decrease in taro growth when it was intercropped with cucumber or cowpea. While taro growth was not affected by intercropping with Jew's mallow or snap bean. They indicated also that the growth characters of Jew's mallow were not affected by intercropping. Bader and Fekry (1998 a) found that the maximum values of growth rate per plant was recorded by growing taro plants on one ridge alternating with cucumber plants on the other ridge. As for the effect of interplanting on plant chemical composition, Mason et al. (1986) showed that intercropping cassava (Manihot esculenta) with cowpeas resulted in $0.8,0.6$ and $0.3 \mathrm{~g} \mathrm{P} / \mathrm{kg}$ and $5.2,4.9$ and $2.9 \mathrm{~g} \mathrm{~N} / \mathrm{kg}$ lower in cassava stems, leaves and storage roots, respectively, at 50 days after sowing than when grown alone. Intercropping had no effect on the N, P, and $\mathrm{K}$ contents of cassava at later harvest dates or of cowpeas at any harvest date. Bader and Fekry (1998 b) reported that growing taro plants on one ridge alternating with the other ridge of cucumber plants was the most effective treatments on $\mathrm{N}, \mathrm{P}, \mathrm{K}$, total carbohydrates and proteins of corms.

Concerning the effect of interplanting on yield and its components, Behairy (1969) reported that growing either bean or cucumber plants on the ridges of dasheen depressed the yield of dasheen. Fatthallah and Gawish (1997) reported that intercropping taro with cucumber or cowpea decreased its yield as compared to sole crop in two seasons. Awah and Mboussi (1999) found that cassava significantly decreased the tuber yields, while its own fresh root yields were only slightly less than when grown sole on cowpea. ELZawily et al. (1993) indicated that the lowest seed yield was obtained when cowpea was planted with cucumber plants on the same side of ridges. Abd El-Baky (1994) found that interplanting cowpea on the ridges of okra decreased average weight of cowpea dry seeds as well as the total yield of 
crop compared with the plants grown alone under the different levels of nitrogen fertilizer. Askar et al. (1997) showed that intercropping bean with cucumber significantly decreased yield of dry bean / feddan. Shiyam et al. (2004) studied the effect of intercropping with cowpea and / or maize on the productivity of banana and they found that intercropping significantly reduced the yields of cowpea and maize. Also, on squash, Rich and Hansen (1982) noticed that intercropping significantly decreased yield / plant in squash when intercropped with bean plants. In addition, Abd El-Baky (2000) reported that the highest yield of squash was obtained when grown as mono crop compared to the intercropped. Fatthallah and Gawish (1997) indicated that yield of jew's mallow was not affected by the intercropping with taro.

Studying the effect of interplanting on associated weeds Unamma et al. (1986) reported that the highest economic returns were obtained from using cowpeas or Egusi melon (Colocynthis citrullus) to suppress weed growth under the cassava and maize. Kolo and Abdullahi (1994) studied the effects of intercropping the cover crops (Citrullus lanatus, watermelons, and cowpeas cv. L 25) with maize cv.TZESR-Y for weed control in maize and they concluded that both cover crops significantly reduced weed growth compared with the control (maize alone). Cowpeas were significantly better for reducing weed growth in maize than with melons.

As for the effect of interplanting on land equivalent ratio (LER), many investigators found that the values of land equivalent ratio resulting from interplanting were more than one. This means that more land is needed for the two sole crops to reach the maximum yield of the two crops. Many of them also indicated that intercropping recorded yield advantage than the sole crops. Rich and Hansen (1982) planted maize, beans (Phaseolus vulgaris) and squash (Cucurbita maxima) in pure stand and mixtures. They reported that land equivalent ratio was greater for all mixtures. Fatthallah and Gawish (1997) indicated that land usage was increased by $84,47,75$, and $42 \%$ in the first season and $82,39,75$, and $42 \%$ in the second season, when taro was intercropped with Jew's mallow, cucumber, snap bean or cowpea, respectively, compared to that obtained if the unit area was sown with sole crop. Recently, Dapaah et al. (2003) showed that cowpea yield was higher when intercropped with two cassava varieties and the intercrops had higher land use ratios (LER=1.27-2.83) and were more stable than the sole crops.

Therefore, the object of this work was to study the effect of interplanting cowpea, squash and Jew's mallow with taro on vegetative growth, mineral contents of taro corms and land equivalent ratio.

\section{MATERIAL AND METHODS}

The experiments were conducted at the Barrage Horticultural Research Station, Kalubia Governorate, during the summer seasons of 2003 and 2004 to study the effect of interplanting of some vegetable crops. The main crop in this experiment was taro cv. Balady. The interplanted crops were cowpea (Vigna unguiculata subsp. unguiculata) cv. Kaha 1, squash 
(Cucurbita pepo) cv. Eskandarani, and Jew's mallow (Chorchorus olitorius) cv. Balady.

The experiments included seven treatments, namely taro alone, cowpea alone, squash alone, Jew's mallow alone, taro with cowpea, taro with squash and taro with Jew's mallow. These treatments were arranged in a randomized complete block design with three replicates. The plot area was $12 \mathrm{~m}^{2}$ included 4 ridges (each was 3 meter in length and 1 meter in width) for taro, Jew's mallow and taro with Jew's mallow. In the case of interplanting cowpea and squash with taro, each ridge was divided into 2 rows $(0.50$ meter in width) one for taro and the other for cowpea or squash interplanting.

Taro cv. Balady was planted on March 17 and 27 in 2003 and 2004 seasons, respectively. Seed pieces from the mother corms were used as planting materials. Seed pieces were inserted at distances of $50 \mathrm{~cm}$ in the row beneath the soil surface for about $5-7 \mathrm{~cm}$.Seeds of cowpea and squash were sown on March 24 and April 2 in 2003 and 2004 seasons, respectively. Cowpea seeds were sown in hills at $20 \mathrm{~cm}$ apart on both side of the ridge ( 0.50 meter in width),squash seeds were sown on one side of the ridge at 50 $\mathrm{cm}$ apart and Jew's mallow seeds were sown on the top of the ridge (one meter in width) at the same time of taro planting.

The systems of planting were the same either in monoculture or in interplanting patterns in both seasons. All cultural practices were applied according to recommendation of the Ministry of Agriculture for each crop.

\section{Data recorded:}

\section{Plant growth measurements:}

a. Taro:

Representive plant samples, each of 3 plants, were picked randomly from each plot at 210 days after taro planting for determining plant height measured from ground level up to the highest petiole, number of leaves per plant, total chlorophyll determined using MINLOTA-SPAD502 Chlorophyll Meter (MINOLTA CO., LTD. Japan), average fresh weight of leaf blades per plant and average dry weight of leaf blades per plant.

\section{b. Cowpea:}

Representive plant samples, each of 3 plants, were picked randomly from the two outer rows of each plot at 45 and 90 days after cowpea seed sowing to determine plant length, number of leaves, fresh and dry weight per plant.

\section{c. Squash:}

Representive plant samples, each of 3 plants, were picked randomly from the two outer rows of each plot at 30 and 60 days after squash sowing to determine plant length, number of leaves per plant, fresh and dry weight per plant.

\section{d. Jew's mallow:}

Representive plant samples, each of 5 plants, were picked randomly from the two outer rows of each plot at 30 and 60 days after Jew's mallow sowing to determine plant length, number of leaves per plant and plant fresh and dry weight per square meter. 


\section{Chemical analysis of taro:}

At the harvest, N, P, K, protein and starch content were determined in corms. Samples of corms were oven dried at $70{ }^{\circ} \mathrm{C}$ till constant weight then used for chemical determinations that were calculated on dry weight basis. Corm content of nitrogen was determined according to the procedure described by FAO (1980). Phosphorus concentration was determined as described by Chapman and Pratt (1961). Potassium concentration was analyzed according to the method described by Brown and Lilliland (1946). Protein content was determined as nitrogen content and converted to its equivalent protein content by multiplying with 6.25 as described by Pregl (1945). Starch content was determined according to A.O.A.C. 1990.

\section{Yield and its components:-}

a. Taro: Taro plants were harvested at 270 days after planting. Height and diameter of the corm, fresh and dry weight of corms / plant, number of cormel / plant, total yield of corms / feddan and total weight of leaves / feddan were recorded.

b. Cowpea: The dry pods were harvested at the end of the cowpea growing season. Number and weight of pods per plot, number and weight of seeds per plot, weight of pods per feddan and weight of seeds per feddan were estimated.

c. Squash: Fruits were harvested through the harvesting season at 3-day intervals and the weight and number of fruits per plant and weight of fruits per feddan were determined.

d. Jew's mallow: The total yield of 2 cuts was measured at 30 and 60 days after sowing.

\section{Associated weeds:}

Weeds appeared in each treatment after 90 days from planting the companion crops were collected and divided into main groups, i.e., annual narrow weeds, annual broad leaved weeds and perennial weeds. Then number, fresh and dry weights of weeds were determined.

\section{Land equivalent ratio (L E R):}

The land equivalent ratio was calculated according to the formula described by Willy and Osiru (1972) using the following Equation:

Since:-

$$
\text { LER }=\text { L. Taro + L. Interplanted crop. }
$$

L. Taro $=\frac{\text { Interplanted yield of taro }}{\text { Pure stand yield of taro }}$

\section{Interplant crop}

L. Cowpea $=\frac{\text { Interplanted yield of cowpea }}{\text { Pure stand yield of cowpea }}$ 
EI-Miniawy, S.M. et al.

L. Squash $=\frac{\text { Interplanted yield of squash }}{\text { Pure stand yield of squash }}$

L. Jew's mallow $=$

Interplanted yield of Jew's mallow

Pure stand yield of Jew's mallow

Statistical analysis:

The data were exposed to proper statistical analysis of variance and combined analysis was done for both years as described by Snedecor and Cochran (1980).

\section{RESULTS AND DISCUSSION}

1. Effect of interplanting on vegetative growth.

a. Effect of interplanting on vegetative growth of taro:

1- Plant height:

The tallest plants were obtained when taro was grown alone (Table 1). Taro plants grown with cowpea tended to be higher than those interplanted with squash or Jew's mallow. The depressions in taro plant height were $2.15 \%, 11.06 \%$ and $32.44 \%$, respectively, when interplanted with cowpea, squash and Jew's mallow compared to taro growing alone. These results are in agreement with those obtained by Behairy (1969) and Fatthallah and Gawish (1997).

2-Number of leaves:

Data in Table (1) revealed that there was no significant effect for interplanting on number of leaves when taro was grown alone or with cowpea. However, interplanting decreased the number of leaves when taro was grown with squash or Jew's mallow and the reduction was significant. Such decreasing effect of the used treatments when compared with the pure stand may be due to the competition between the two intercropped plants as mentioned by Bader and Fekry (1998b).

Table 1. Effect of interplanting cowpea, squash or Jew's mallow with taro on plant height, number of leaves per plant, chlorophyll, fresh and dry weight of leaf blade of taro plant at 210 days after planting (combined analysis of two growing seasons).

\begin{tabular}{lccccc} 
Treatments & $\begin{array}{c}\text { Plant } \\
\text { height } \\
\text { (cm) }\end{array}$ & $\begin{array}{c}\text { Number of } \\
\text { leaves per } \\
\text { plant }\end{array}$ & $\begin{array}{c}\text { Chlorophyll } \\
\text { SPAD } \\
\text { reading }\end{array}$ & $\begin{array}{c}\text { Leaf blade per plant } \\
\text { Fresh weight } \\
\text { (gm) }\end{array}$ & $\begin{array}{c}\text { Dry } \\
\text { weight (gm) }\end{array}$ \\
\hline Taro alone & 155.14 & 4.48 & 42.74 & 841.66 & 139.84 \\
Taro with cowpea & 151.79 & 4.44 & 41.00 & 858.88 & 143.70 \\
Taro with squash & 137.97 & 4.16 & 39.71 & 580.55 & 97.88 \\
Taro with Jew's mallow & 104.81 & 3.97 & 37.55 & 416.66 & 72.13 \\
L.S.D at 5\% & 1.2 & 0.20 & 0.24 & 39.37 & 6.14 \\
\hline
\end{tabular}




\section{3- Total chlorophyll:}

The highest values of chlorophyll were obtained when taro was grown alone (Table1) and significantly decreased when interplanted with cowpea, squash and Jew's mallow.

\section{4- Fresh and dry weight of leaf blade:}

Taro alone or interplaned with cowpea gave the highest fresh and dry weight of leaf blade and interplanting taro with squash or Jew's mallow decreased fresh and dry weight significantly. Mason et al. (1986) on cassava came to similar results.

\section{b. Effect of interplanting on vegetative growth of cowpea: \\ 1- Plant length:}

Results presented in Table (2) showed that the average of plant length was higher in solid cowpea than in interplanted cowpea. The depression in cowpea plant length was $12.77 \%$ and $10.29 \%$ compared to planting cowpea alone at 45 and 90 days, respectively. The depression in cowpea plant length could be due to the competition for nutrients and place, as well as other environmental factors. The obtained results are in harmony with those reported by Behairy (1969).

Table 2. Effect of intertplanting with taro on vegetative growth of cowpea, squash and Jew's mallow plants (combined analysis of two growing seasons).

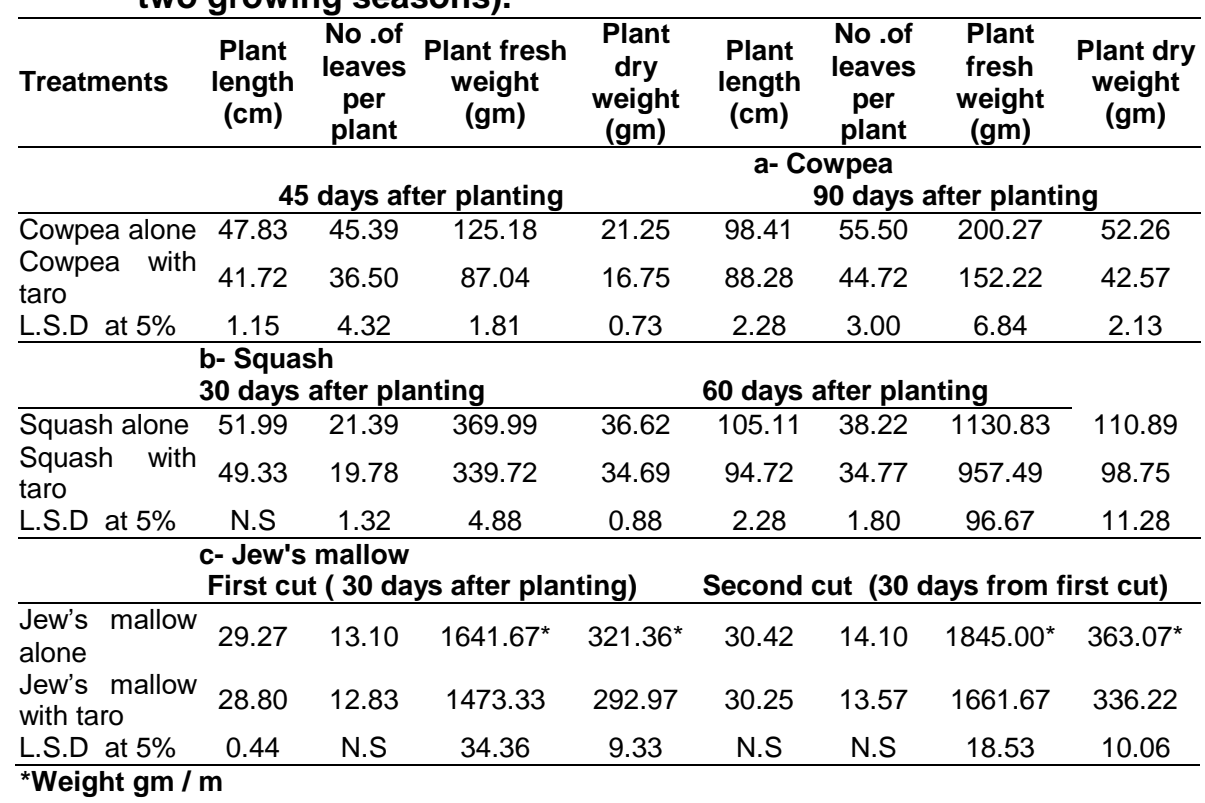

\section{2- Number of leaves:}

The higher number of leaves per plant was recorded for cowpea alone compared to those interplanted with taro at both 45 and 90 days after planting. 


\section{3- Plant fresh and dry weight:}

Interplanting cowpea with taro (Table 2) significantly decreased the plant fresh and dry weight by $30.46 \%$ and $23.99 \%$ for the fresh weight and $21.17 \%$ and $18.54 \%$ for the dry weight due to interplanting cowpea with taro at both sampling dates, respectively, compared to solid cowpea. Abd ElBaky (1994) came to similar results.

\section{c. Effect of interplanting on vegetative growth of squash: \\ 1- Plant length:}

After 30 and 60 days from planting significant reduction occurred in plant length of squash interplanted with taro comparing with squash alone. This agrees with the views of Behairy (1969) and Fatthallah and Gawish (1997).

\section{2- Number of leaves per plant:}

Interplanting squash with taro had a significant effect on number of leaves per squash plant (Table 2).Squash plants growing alone recorded the higher values of number of leaves per plant. Whereas, interplanting squash with taro gave the lower number of leaves per plant at 30 and 60 days after planting.

\section{3- Plant fresh and dry weight}

Results presented in Table (2) indicated that the fresh and dry weight of squash plants grown alone significantly exceeded those grown with taro. These results were true at both sampling dates,i.e., after 30 and 60 days from planting. Rich and Hansen (1982) mentioned that vegetative biomass / plant in squash was significantly smaller in mixture with maize than in pure stands. Similar findings have been found by Abd El- Baky (1994).

\section{d. Effect of interplanting on vegetative growth of Jew's mallow:}

\section{1 - Plant length:}

The length of Jew's mallow plant interplanted with taro was shorter (Table 2) than that of Jew's mallow grown alone. The decrease was slight but significant in the first cut. While, in the second cut, no significant effect was observed for interplanting Jew's mallow with taro on Jew's mallow plant length. The obtained results are in harmony with those reported by Ojeifo and Lucas (1987).

\section{2 - Number of leaves:}

There was no significant difference in leaf number between Jew's mallow grown alone and the interplanted with taro (Table 2).The results were similar in the first and second cut. The obtained results are in harmony with those reported by Fatthallah and Gawish (1997).

3- Fresh and dry weight:

Interplanting had significant reducing effects on fresh and dry weight / $\mathrm{m}^{2}$ of Jew's mallow (Table 2). The reduction was $10.25 \%$ and $9.94 \%$, for fresh weight and $8.83 \%$ and $7.39 \%$ for dry weight in the first and second cut, respectively.

\section{Effect of interplanting on chemical composition of taro corms:}

Taro grown alone or interplanted with cowpea showed the highest percentage of $\mathrm{N}$, protein and starch compared to taro with squash or Jew's mallow (Table 3). The differences of $\mathrm{N}$, protein and starch percentage of taro 
corms when interplanting with squash or Jew's mallow were not significant. Bader and Fekry (1998 b) on taro came to similar conclusion.

Data in Table (3) revealed also that the $\mathrm{P}$ and $\mathrm{K}$ percentages of taro corms did not differ significantly by interplanting any crop with taro. This trend agrees with that of Mason et al. (1986) on cassava.

Table 3. Effect of interplanting cowpea, squash or Jew's mallow with taro on chemical composition of taro corms (combined analysis of two growing seasons).

\begin{tabular}{lccccc}
\hline Treatments. & $\begin{array}{c}\text { Nitrogen } \\
\%\end{array}$ & $\begin{array}{c}\text { Phosphorus } \\
\%\end{array}$ & $\begin{array}{c}\text { Potassium } \\
\%\end{array}$ & $\begin{array}{c}\text { Protein } \\
\%\end{array}$ & $\begin{array}{c}\text { Starch } \\
\%\end{array}$ \\
\hline Taro alone & 0.409 & 0.273 & 2.625 & 2.562 & 50.584 \\
Taro with cowpea & 0.406 & 0.264 & 2.651 & 2.541 & 50.212 \\
Taro with squash & 0.345 & 0.269 & 2.525 & 2.159 & 46.184 \\
Taro with Jew's mallow & 0.315 & 0.262 & 2.470 & 1.969 & 44.009 \\
L.S.D at 5\% & 0.04 & N. S & N. S & 0.21 & 2.61 \\
\hline
\end{tabular}

\section{Effect of interplanting on total yield and its components:} a-Taro:

It is clear from Table (4) that interplanting taro with cowpea, squash or Jew's mallow had a significant effect on corm height and diameter. Taro interplanted with cowpea had the highest corm height and diameter. Interplanting cowpea with taro increased significantly fresh weight of corms per plant by $2.15 \%$ compared to taro grown alone. However, interplanting squash or Jew's mallow reduced the fresh weight of corms per plant by 21.82 $\%$ and $49.88 \%$, respectively, compared to fresh weight of taro grow alone. No significant effect was observed for interplanting cowpea with taro or taro grown alone on dry weight of corms per plant (414.11 and $405.34 \mathrm{~g} /$ plant, respectively). While, taro interplanted with squash or Jew's mallow decreased significantly the dry weight of corms per plant (316.7 and 200.31, respectively). Interplanting cowpea with taro increased the number of cormels per plant than taro grown alone but the difference was not significant. Although, taro with squash had 3.67 cormels per plant and taro with Jew's mallow had the lowest number of cormels (2.83).

As for yield, it is evident from Table (4) that interplanting cowpea with taro showed the highest taro yield (14.1 ton /feddan) followed in decreasing order by taro alone (13.62 ton /feddan), squash interplanted with taro (11.53 ton / feddan) and Jew's mallow interplanted with taro (7.07 ton /feddan). The yield increased by $3.52 \%$ when interplanting cowpea with taro. However the yield decreased by $15.34 \%$ or $48.09 \%$, when interplanting squash or Jew's mallow, respectively, with taro as compared with taro grown alone. Illustrated data in Table (4) show that interplanting cowpea with taro increased weight of leaves per feddan (8.01 ton / feddan) than taro alone ( 7.85 ton/feddan) with no significant differences between them. Interplanting squash and Jew's mallow decreased significantly the weight of taro leaves per feddan. The obtained results are in harmony with those of reported by Behairy (1969), Fatthallah and Gawish (1997) and Awah and Mboussi (1999). 
Table 4. Effect of interplanting cowpea, squash or Jew's mallow with taro on the yield and its components of taro plants at harvest (270 days after planting ) combined analysis of two growing seasons.

\begin{tabular}{lccccccc}
\hline Treatments & $\begin{array}{c}\text { Corm } \\
\text { height } \\
\text { (cm) }\end{array}$ & $\begin{array}{c}\text { Corm } \\
\text { diameter } \\
\text { (cm) }\end{array}$ & $\begin{array}{c}\text { F.W. plant } \\
\text { (gm) }\end{array}$ & $\begin{array}{c}\text { D.W. } \\
\text { plant } \\
\text { (gm) }\end{array}$ & $\begin{array}{c}\text { No. of } \\
\text { cormels } \\
\text { plant }\end{array}$ & $\begin{array}{c}\text { Yield of } \\
\text { corms } \\
\text { ton/fed }\end{array}$ & $\begin{array}{c}\text { Yield of } \\
\text { leaves } \\
\text { ton/fed }\end{array}$ \\
\hline Taro alone & 15.31 & 11.36 & 1700.52 & 405.34 & 4.61 & 13.62 & 7.85 \\
Taro with cowpea & 15.54 & 11.62 & 1737.22 & 414.11 & 4.83 & 14.10 & 8.01 \\
Taro with squash & 13.75 & 11.25 & 1329.44 & 316.70 & 3.67 & 11.53 & 5.42. \\
Taro with Jew's mallow & 11.61 & 9.69 & 852.22 & 200.31 & 2.83 & 7.07 & 3.88 \\
L.S.D at 5\% & 0.37 & 0.17 & 34.88 & 10.08 & 0.26 & 0.24 & 0.37 \\
\hline
\end{tabular}

\section{b-Cowpea:}

Concerning the effect of interplanting cowpea with taro on number and weight of pods per plot, data reported in Table (5) indicated that number and weight of pods per plot were higher when cowpea was grown alone than interplanting cowpea with taro. Cowpea interplanted with taro significantly decreased the number of pods by $34.04 \%$ and the weight of pods per plot by $37.10 \%$ compared to planting cowpea alone. The number and weight of dry seeds per plot was decreased comparing with planting cowpea alone. In this connection, Abd El- Baky (1994) observed that interplanting cowpea with okra decreased average weight of cowpea dry seeds.

Concerning yield, the results in Table (5) showed that cowpea intercropped with taro gave fewer yield of pods per feddan $(602.77 \mathrm{~kg} /$ feddan) than cowpea grown alone $(958.32 \mathrm{~kg} /$ feddan). These results agree with those of Shiyam et al. (2004), who mentioned that intercropping significantly reduced the yields of cowpea when itercropped with banana. In addition, cowpea grown in pure stands produced greater seed yield per feddan $(479.21 \mathrm{~kg} / \mathrm{feddan})$ than cowpea interplanted with taro $(333.64 \mathrm{~kg} /$ feddan). The reduction in seed yield was $30.38 \%$ comparing with planting cowpea alone. This reduction in seed yield might be attributed to the nitrogen translocation from cowpea to taro plants as mentioned by Askar et al. 1997. Similar conclusions were obtained by El-Zawily et al. (1993) on cowpea.

Table 5. Effect of intertplanting cowpea with taro on yield and its components of cowpea plants (combined analysis of two growing seasons).

\begin{tabular}{lcccccc}
\hline Treatments & $\begin{array}{c}\text { Number of } \\
\text { pods/plot }\end{array}$ & $\begin{array}{c}\text { Weight of } \\
\text { pods } \mathbf{( g m}) \\
\text { /plot }\end{array}$ & $\begin{array}{c}\text { Number of } \\
\text { dry seeds } \\
\text { /plot }\end{array}$ & $\begin{array}{c}\text { Weight of } \\
\text { dry seeds } \\
\text { (gm)/plot }\end{array}$ & $\begin{array}{c}\text { Yield of } \\
\text { dry pods } \\
\text { (kg)/fed }\end{array}$ & $\begin{array}{c}\text { Yield of } \\
\text { dry seeds } \\
\text { (kg)/fed }\end{array}$ \\
\hline Cowpea alone & 1903.57 & 2875.00 & 9551.18 & 1437.62 & 958.32 & 479.21 \\
Cowpea with taro & 1255.67 & 1808.33 & 5872.00 & 1000.92 & 602.77 & 333.64 \\
L.S.D at 5\% & 182.87 & 106.14 & 448.22 & 72.039 & 35.392 & 24.01 \\
\hline
\end{tabular}

\section{C- Squash:}

As shown from Table (6), interplanting squash with taro reduced significantly the number and weight of fruits per plant and per plot, compared with the single squash plantation. Similar results have been reported by Rich and Hansen (1982), who indicated that intercropping significantly decreased 
squash yield. The obtained results are in harmony with those reported by Fatthallah and Gawish (1997), who found that the yield and its components of cucumber was significantly decreased by intercropping taro with cucumber as compared to sole cropping.

Regarding yield, the results indicated that the effect of interplanting squash with taro on the number and weight of fruits per feddan of squash plants were higher in squash plants grown alone than squash plants grown with taro. In other words, reduction in the yield was $26.27 \%$ for squash interplanting with taro compared to squash grown alone. These results my be attributed to the competition for nutrients and water absorption between the mixed crops as mentioned by Abd El- Baky (2000). Also, Askar et al. (1997) found that intercropping bean with cucumber significantly decreased total yield of cucumber. Abd El- Baky (2000) noted that the highest yield of squash was obtained when grown as mono crop compared to the intercropping.

Table 6. Effect of intertplanting squash with taro on yield and its components of squash plants (combined analysis of two growing seasons).

\begin{tabular}{lccccc}
\hline Treatments & $\begin{array}{c}\text { Number of } \\
\text { fruits/plant }\end{array}$ & $\begin{array}{c}\text { Weight of } \\
\text { fruits } \\
\text { (gm)/plant }\end{array}$ & $\begin{array}{c}\text { Number of } \\
\text { fruits/ } \\
\text { plant }\end{array}$ & $\begin{array}{c}\text { Weight of } \\
\text { fruits } \\
\text { (Kg)/plant }\end{array}$ & $\begin{array}{c}\text { Yield of } \\
\text { fruits } \\
\text { (ton)/fed }\end{array}$ \\
\hline squash alone & 5.23 & 536.22 & 125.57 & 12.87 & 4.30 \\
squash with taro & 3.83 & 395.90 & 92.00 & 9.50 & 3.17 \\
L.S.D at 5\% & 0.49 & 23.68 & 11.71 & 0.57 & 0.20 \\
\hline
\end{tabular}

\section{d- Jew's mallow:}

It is evident from Table (7) that interplanting Jew's mallow with taro reduced the yield of Jew's mallow. The total Yield of Jew's mallow grown alone was higher than the obtained yield from interplanting (13.95 ton/feddan and 12.54 ton/feddan, respectively). This reduction in the yield was $10.11 \%$ compared with single plantation of Jew's mallow.

Table 7. Effect of intertplanting Jew's mallow with taro on the yield of Jew's mallow plants (combined analysis of two growing seasons).

\begin{tabular}{lccc}
\hline Treatments & $\begin{array}{c}\text { Yield per square } \\
\text { meter } \\
(\mathbf{g m})\end{array}$ & $\begin{array}{c}\text { Yield per plot } \\
\text { ( Kg) }\end{array}$ & $\begin{array}{c}\text { Expected yield per } \\
\text { feddan } \\
\text { (ton) }\end{array}$ \\
\hline Jew's mallow alone & 3486.67 & 41.84 & 13.95 \\
Jew's mallow with taro & 3135.00 & 37.62 & 12.54 \\
L.S.D at 5\% & 34.36 & 0.41 & 0.13 \\
\hline
\end{tabular}

\section{Effect of interplanting on associated weeds:}

The prevailing weeds in the experiment during the two growing seasons were nutsedage (Cyperus rotundus), bermuda grass (Cynodon dactylon ) and field bind -weed (Convolvulus $c$ ) as perennial weeds. The main annual broad - leaved weeds were lambs quarter (Chenopdium abum) and purslame (Portulace deracea) while abou Rokba (Echinochloa colonum) as annual narrow weeds. Weeds in each plot were hand - pulled, separated 
and classified into three groups: annual narrow weeds, annual broad-leaved weeds and perennial weeds. Number, fresh and dry weight of weeds per unit area could be used as a reliable index to distribution.

Data in Table (8) revealed that interplanting cowpea or squash with taro reduced significantly number of weeds $/ \mathrm{m}^{2}$ after 90 days from taro planting. However, interplanting Jew's mallow with taro had no effect on weed control. The highest number of weeds was recorded by taro alone or Jew's mallow alone. Concerning cowpea alone or squash alone they gave low values of weed number than Jew's mallow alone. Interplanting cowpea, squash or Jew's mallow with taro had significant effects on fresh weight of the associated weeds. Jew's mallow grown alone exhibited the highest values of annual narrow weeds, annual broad leaved weeds and perennial weeds fresh weight at 90 days from taro planting followed by taro grown alone and taro with Jew's mallow. Whereas interplanting cowpea or squash with taro recorded low values of fresh weight of weeds compared to growing cowpea or squash alone. It could be suggested that the highest fresh weight of these weeds was correlated with individual plantation of Jew's mallow, taro, squash and cowpea. The lowest fresh weight was recorded with mixed plantation of cowpea with taro and squash with taro.

Concerning the effect of interplanting on dry weeds $/ \mathrm{m}^{2}$ after 90 days from taro planting, taro alone had the highest value of dry weight of weeds / $\mathrm{m}^{2}$ followed by Jew's mallow alone and taro with Jew's mallow compared with taro with cowpea and taro with squash which had the lowest values. In other words, interplanting cowpea or squash with taro significantly decreased the dry weight of weeds $/ \mathrm{m}^{2}$ in the field of taro. This agrees with the views of Unamma et al. (1986) and Kolo and Abdullahi (1994)

\section{Land equivalent ratio (LER):}

Data in Table (9) indicated that the values of LER were greater than one by interplanting although the yield of each crop was greater when it was grown alone than as combined crop. This means that yield advantage was obtained and land usage was increased by interplanting. In other words, interplanting was more efficient than sole cropping. The land usage increased by $74 \%, 59 \%$ or $42 \%$ when interplanting cowpea, squash or Jew's mallow with taro, respectively, than that obtained if the unit area was planted with sole crops. The obtained yield advantage may be due to the differences in rooting system of taro plants or companion crops, nutrient requirements and efficiency of photosynthesis process. Thus they are able to complement each other and to make better overall use of environmental resources when grown in combination than grown separately as mentioned Fatthallah and Gawish (1997).The obtained results on taro are in harmony with those of Awah and Mboussi (1999) and Dapaah et al. (2003).On squash, Rich and Hansen (1982) reported that land equivalent ratio was greater for all mixtures when planting maize, beans and squash in pure stands and mixtures. 
J. Agric. Sci. Mansoura Univ., 32 (3), March, 2007

T8

$r 1 \leqslant 0$ 
Generally, it could be concluded that it is capable to use the interplanting system in case of taro cultivation. Moreover, in case of using this system it is better to choose cowpea than squash or Jew's mallow to be cultivated with taro, because cowpea is less competitive to taro than squash or Jew's mallow.

Table 9. Effect of interplanting cowpea, squash or Jew's mallow with taro on land equivalent ratio (combined analysis of two growing seasons).

\begin{tabular}{lc}
\hline Treatments & L E R \\
\hline LER of taro & 1.04 \\
LE R of cowpea & 0.70 \\
Total LE R & 1.74 \\
\hline LE R of taro & 0.85 \\
LE R of squash & 0.74 \\
Total LE R & 1.59 \\
\hline LE R of taro & 0.52 \\
LE R of Jew's mallow & 0.90 \\
Total LE R & 1.42 \\
\hline
\end{tabular}

\section{REFERENCES}

Abd EL-Baky, M.M.H. (1994). Effect of interplanting on growth and productivity of some vegetable plants. M.Sc. Thesis Fac. Agric. Ain Shams Univ., Egypt.

Abd EL-Baky, M.M.H. (2000). Productivity of some vegetable crops as affected by intercropping system. Ph.D. Thesis, Fac. Agric. Ain Shams Univ., Egypt.

A.O.A.C. (1990). Official Methods of Analysis Association of Official Analytical Chemists. Washington, D.C., pp. 59 - 60.

Askar, El-S.H.; F.A. El-Bary and S.M. El-Gizy (1997). Effect of some intercropping systems on the vegetative growth, productivity and yield components of cucumber and dry bean. J. Agric. Sci. Mansoura Univ., 22 (7): 2377-2386.

Awah, E.T. and M.A. Mboussi (1999). The performance of cassava and tuber intercrops in the humid forest zone of Cameroon. Tropical Science, 39 (3): 183-185.

Bader, L.A.A. and W.A. Fekry (1998a). Effect of intercropping and level of fertilization on growth and productivity of taro and cucumber plants. 1 . Vegetative growth and chemical constituents of foliage. Zagazig J. Agric. Res., 25 (6):1087-1101.

Bader, L.A.A. and W.A. Fekry (1998b). Effect of intercropping and level of fertilization on growth and Productivity of taro and cucmber plants. 2. Yield and quality characteristics. Zagazig J. Agric. Res., 25 (6): 11031123.

Behairy, A.G. (1969). Effect of interplanting some vegetable plants in dasheen ridges on competition between them. Ph.D. Thesis, Fac. Agric. Ain Shams Univ., Egypt. 
Brown, J. and O. Lilliland (1946). Rapid determination of potassium and sodium in plant material and soil extracts by flame photometric. Proc. Amer. Soc. Hort. Sci ., 48: 341-346 .

Chapman, H.D. and P.F. Pratt (1961). Methods of Analysis for Soil, Plant and Water. Calif., Univ. UAS. PP.94-197.

Dapaah, H.K.; J.N. AsafuAgyei; S.A. Ennin and C. Yamoah (2003). Yield stability of cassava, maize, soya bean and cowpea intercrops. Journal of Agricultural Science, 140 (1):73-82.

EL-Zawily, A.I.; A.A. Etman; M.H. Kassem and E.I. Metwally (1993). Productivity of cucumber under different intercropping systems and spacings of cowpea. J. Agric. Res. Tanta Univ., 19 (2): 439-447.

FAO (1980). Soil and Plant Analysis. Soils Bulletin 38, 2, 250.

Fatthallah, M.A. and R.A. Gawish (1997). Effect of taro intercropping with some vegetable crops on growth, yield and land productivity in relation to several soil miosture regimes. Menofiya J. Agric. Res., 22 (6): 16471675.

Jensen, E.S. (1996). Grain yield, symbiotic N2-fixation and interspecific competition for inorganc $\mathrm{N}$ in pea-barley intercrops. Plant and Soil, 182: 25-38. (C.F.CAB Abst.).

Kolo, M.G.M. and U.B. Abdullahi (1994). Low growing crops as weed suppraessants in intercropping systems. Indian J. Agric. Sciences, 64(9): 642-643. (C.F.CAB Abst.).

Mason, S.C.; D.E. Leihner and J.J. Vorst (1986). Cassava-cowpea and cassava-peanut intercropping III. Nutrient concentration removal. Agron. J., 78 (3): 441-444. (C.F.CAB Abst.).

Ojeifo, I.M. and E.O. Lucas (1987). The growth and development of Corchorus olitorius (L.) grown alone and intercropped with tomato (Lycopersicon esculentum Mill.). J. Agric. Sci., 109: 39-45.

Pregl, F.E. (1945). Quantitative organic microanalysis, $4^{\text {th }}$ ed., pp. 146-152, Churchill, London .

Rich, S.J. and M.K. Hansen (1982). Plant growth, flowering, phenologies, and yields of corn, beans and squash grown in pure stands and mixtures in Costa Rica. J. of Applied Ecology, 19 (3): 901-916. (C.F. Hort .Abst. 53 (6): 4156, 1983).

Snedecor, G.W. and W.G. Cochran (1980). Statistical Method. $7^{\text {th }}$ ed., lowa State Univ. Press, Ames lowa, USA.

Shiyam, J.O.; B.F.D. Oko and B.W. Binang (2004). Productivity of a False horn plantain intercropped with cowpea and maize in southeastern Nigeria.Infomusa, $13 \quad$ (1):18-20. (http://www.inibap.org//N040524_en.pdf).

Unamma, R.P.A.; L.S.O. Ene; S.O. Odurukwe and T. Enyinnia (1986). Integrated weed management for cassava intercropped with maize. Weed Research, 26 (1): 9-17.

Willy, R.W. (1979). Intercropping, its importance and research needs. Part.1.Competition and yield advantages. Field Crop Abstr.32 (1): 1-10. 


\section{El-Miniawy, S.M. et al.}

Willy, R.W. and S.O. Osiru (1972). Studies on mixtures of maize and beans Phaseolus vulgaris with particular reference to plant population. J. Agric. Sci., Cambridge, 79: 519.

الزراعة البينية لللوبيا و الكوسة و الملوخية مع القلقاس

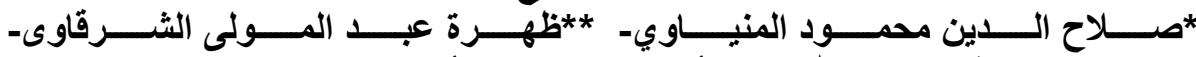

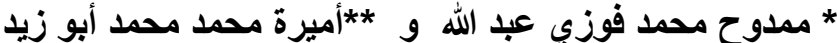

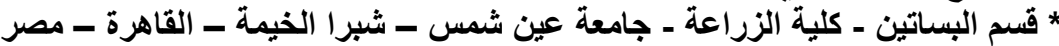

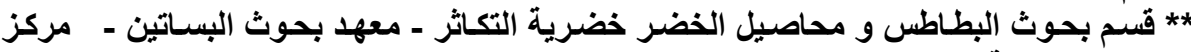

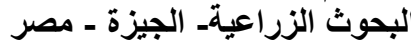

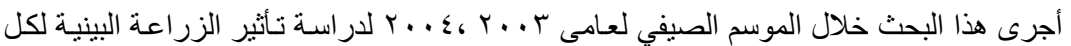

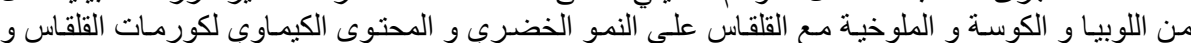

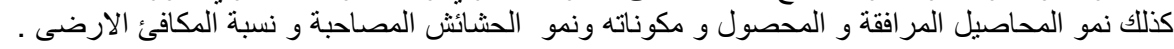
و يمكن تلخيص النتائج المتحصل عليه الفيها كالاتى: ( ـ أدت الزراعة البينية لكل من اللوبياو الكوسة و الملوخية مع القلقاس إلى نقص معنوي في النمو الخضري

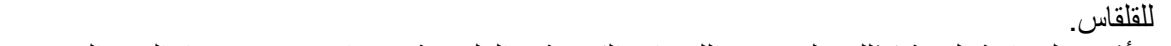
r ـ أثرت الزراعة البينية كذلك على نمو اللوبيا و الكوسة و الملوخية فقد انخفض معنويـا النمو الخضري

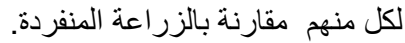
r - أعلى قيم لمحتوى كورمات القلقاس من النيتروجين و البروتين و و النثا كانت عند زر راعة القلقاس منفردا

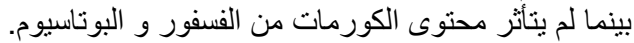

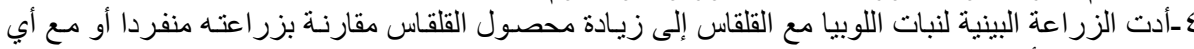

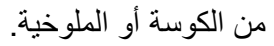
بالإضافة إلى ذلك فان محصول كلا من اللوبياو الكوسة و الملوخية كان أعلى في حالة الزر اعة المنفردة عنه في مالة زر اعتهم مع القلقاس.

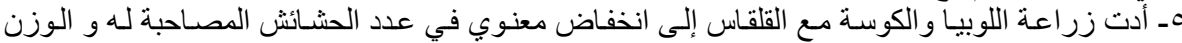

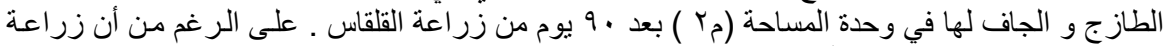

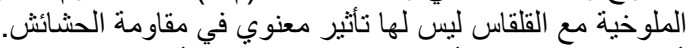

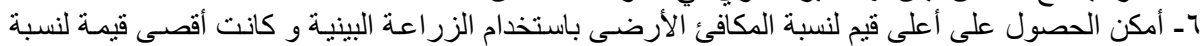

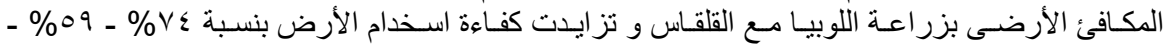
بـ

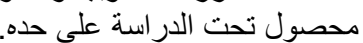

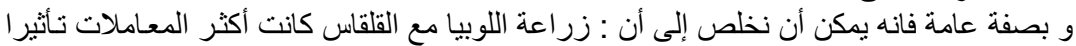

و أفضلية في معظم الحالات تحت ظروف هذه التجربة حيث أن اللوبيا لا تعتبر محصو لا منافسا بدرجة كبيرة . 
J. Agric. Sci. Mansoura Univ., 32 (3), March, 2007 
Table 8. Effect of interplanting cowpea, squash or Jew's mallow with taro on number, fresh and dry weight of weeds $/ \mathrm{m}^{2}$ at 90 days from taro planting (combined analysis of two growing seasons).

\begin{tabular}{|c|c|c|c|c|c|c|c|c|c|}
\hline \multirow[b]{2}{*}{ Treatments } & \multicolumn{3}{|c|}{ Number of weeds } & \multicolumn{3}{|c|}{ Fresh weight of weeds } & \multicolumn{3}{|c|}{ Dry weight of weeds } \\
\hline & $\begin{array}{l}\text { Annual } \\
\text { narrow }\end{array}$ & $\begin{array}{c}\text { Annual } \\
\text { broadleaved }\end{array}$ & Perennial & $\begin{array}{l}\text { Annual } \\
\text { narrow }\end{array}$ & $\begin{array}{c}\text { Annual } \\
\text { broadleaved }\end{array}$ & Perennial & $\begin{array}{l}\text { Annual } \\
\text { narrow }\end{array}$ & $\begin{array}{c}\text { Annual } \\
\text { broadleaved }\end{array}$ & Perennial \\
\hline Taro alone & 82.00 & 67.33 & 98.67 & 376.56 & 446.00 & 267.25 & 44.91 & 53.74 & 71.10 \\
\hline Taro with cowpea & 38.67 & 46.00 & 50.00 & 229.35 & 260.19 & 184.40 & 31.11 & 35.23 & 40.91 \\
\hline Taro with squash & 50.67 & 54.67 & 56.67 & 258.97 & 278.15 & 194.97 & 34.25 & 42.35 & 52.30 \\
\hline Taro with Jew's mallow & 66.00 & 69.33 & 88.00 & 331.93 & 378.94 & 220.30 & 39.99 & 47.03 & 60.92 \\
\hline Cowpea Alone & 46.67 & 50.67 & 67.33 & 270.21 & 278.61 & 190.14 & 35.18 & 41.68 & 52.12 \\
\hline Squash Alone & 52.00 & 59.33 & 74.67 & 289.09 & 304.23 & 204.53 & 36.01 & 45.61 & 55.17 \\
\hline Jew's mallow alone & 88.68 & 76.67 & 91.33 & 380.88 & 462.15 & 234.12 & 44.74 & 52.78 & 63.27 \\
\hline L.S.D at $5 \%$ & 4.79 & 4.07 & 4.34 & 19.71 & 24.74 & 9.62 & 1.80 & 2.46 & 2.21 \\
\hline
\end{tabular}

